\title{
Economic Analysis of Seedlings Plant Productions in Nurseries within Bauchi Metropolis in Nigeria
}

\author{
Ephraim, K. Rabo ${ }^{1, *}$, Abubakar, E. Mazadu² \\ ${ }^{1}$ Department of Agric. Extension and Management, College Of Agriculture, Bauchi \\ ${ }^{2}$ Department of Forestry Technology, College of Agriculture, Bauchi
}

*Corresponding Author: Ephraim, K. Rabo, Department of Agric. Extension and Management, College of Agriculture, Bauchi

\begin{abstract}
Seedling nurseries are mean of self-employment opportunity that generates income with relatively low investment expenditure in the study area. This study examined the viability of seedling production in nurseries within Bauchi metropolis with the aim of investigating whether it is financially feasible for young to engage in seedling productions in order to reduce the rate of unemployment in the Bauchi metropolis. Eight wards were selected randomly within the metropolis, in each of the wards, five nurseries were randomly selected; in each nursery, 3 respondent was administered with the questionnaire. Most of the nursery operators were within the age of 18 to 35 years. This age bracket composed of youths and few adults; this implied that commercial nursery business in the study area can be greatly improved upon, since it is concentrated mostly in the hands of young and agile individuals. The seedlings identified at the nurseries consisted of 24 species; 14 ornamental species, 8 tree crops species and 4 forest species. The result of the economic analysis from this study showed that the rate of returns (RORT) was high with the highest returns on Golden Palm (N2,350), Ficus (N1,193.33), Yellow bush (N1,050) and Gmelina (N1,033.33). Inadequate funds and water supply were the major constraint to seedlings production in the study area; therefore, there is need for Government and NGOs to assist nursery operators with loan to start up or expand the existing nursery business. Nursery business is an attractive business to the people in the metropolis and specifically to the unemployed youths. There is great need for adoption of this enterprise in order to reduce poverty and unemployment rate in the study area.
\end{abstract}

Keywords: Seedling, ornamental plants nursery, Nursery, Bauchi metropolis, unemployment.

\section{INTRODUCTION}

Nurseries have the common goal of producing plant material for improving sites. They are established to produce seedlings, grown under favorable conditions at germination and early growth stage before transplanting to the field for planting purpose. Plant nurseries can be an informal, small- scaled arrangement or a large commercial enterprise that vary in size, facilities (supplies, tools, equipment, etc.), types of seedlings produced, and operations (Larinde and Ruth, 2014).

High quality seedlings are fundamental to the successful establishment of orchards and plantations, both for timber production and reforestation of degraded land/environments. Recently, the production of both cut flowers and home plants has continued to increase steadily in most urban and metropolises. The importance of ornamental plants in human life cannot be over-emphasized. Ornamental plants are not only sources of medicinal herbs (Fakayode et al., 2008). Ornamental plants also serve as environmental stimulants that trigger pleasant memories. These plants also play crucial role in cooling the atmosphere through the evapo-transpiration process on their leaves and other parts thereby preventing health hazards (Omokhua, et al, 2002).

People are increasingly realizing the need for planting trees, shrubs and grasses for different purposes, especially in the urban and metropolises. Plant seedling nurseries provide employment opportunity for the urban youths. The job including skilled-labour such as green-house and nursery managers and jobs for individuals involved in the cultivation and marketing of the ornamental plants (Fakayode et al., 2008). 
The contribution of small-scale plant nursery enterprise (which is a self employment business) in economic development both to the individual and to the nation's economy cannot be overemphasized (Babalola, 2008). Small-scale nursery establishments are highly profitable business ventures in Nigeria due to the short time between production and sale of most of the plants involved (Aiyeloja and Larinde. 2006). Mailumo et al. (2006) in their socio-economic analysis of tree seedling production in nurseries in Abuja, Federal Capital Territory (FCT), Nigeria concluded that the business is profitable with the owners realizing an average profit of N277, 108 from an average nursery size of 0.2ha (Larinde and Ruth, 2014).

Despite all the great potentials of the ornamental plants business to improve the economy of nations, the sector in Nigeria has been hampered by many problems. It has also received very little attention in the nation's perspective plan for agricultural development (Oseni, 2004). Most ornamental plant nurseries are under-developed in Nigeria (Bankole, 2002). Thus, there is need to assess the type and quantity of seedlings produced by the seedling operators; estimate the rate of return of investment on seedling production and to identify the problems of commercial nursery operators in the study area. Thus, this study would help to enhance the aesthetic nature of towns and cities for the purposes of conservation, environmental protection, production, beautification and revenue generation; consequently commercial seedling production centre have gained attention and patronage in some areas especially in most of the metropolis in the Nigeria.

\section{METHODOLOGY}

\subsection{Study Area}

Bauchi metropolis is located between Latitude $10^{\circ} 22^{\prime}$ North of the equator and Longitude $9^{\circ} 42^{\prime}$ East of the Greenwich Meridian at an elevation of $607.4 \mathrm{~m}$ above sea level. It has land area of $3,687 \mathrm{~km}^{2}$ with a population of 493,840 (Dau and Elisha, 2013). The predominant tribes are 'Gerawa, Fulani and Hausa'. Human cultivation include: farming, hurting, business, civil service, etc., (Nigerian National Bureau of Statistics, 2010).

\subsection{Sampling Design and Data Collection}

Multi-stage sampling design was used for data collection. Eight (8) council wards were randomly selected in the study area; in each of the wards, 5 plant seedlings nurseries were selected and in each nursery, 3 respondents were randomly selected from each nursery giving a total of 120 respondents. The data used for the study were collected from the managers and workers of various nurseries in the study area.

Data were collected through administered of structured questionnaire and interviewed. These involved questions related to the operational activities, rate of return and problems encountered in seedling productions in the study area. The seedling species found at the nurseries were identified by common names.

\subsection{Data Analysis}

Descriptive statistic (frequencies and percentage) was used analyze the data gathered from the study area. The economic evaluation of nursery seedling was estimated using Gross profit margin (GM) and Rate of return (RORT). Gross profit margin is the difference between revenue and cost before accounting for certain other costs. It was calculated as the selling price of an item, less the cost of goods sold (production or acquisition costs, essentially). The purpose of margins is to determine the value of incremental sales, and to guide pricing and promotion decision (Farris et al., 2010).

Margin on sales represents a key factor behind many of the most fundamental business considerations, including budgets and forecasts. The gross margin was estimated with the following formula (Larinde and Ruth, 2014)

Gross profit margin $=\mathrm{TR}-\mathrm{TVC}$

Where $\mathrm{TR}=$ total revenue and $\mathrm{TVC}=$ Total variable cost

In finance, rate of return (RORT) is the ratio of money gained or lost on an investment relative to the amount of money invested. The rate of return was estimated using the formula:

$\mathrm{RORT}=\frac{T R-T C}{T C} \times 100$

Where $\mathrm{TR}=$ Total revenue and $\mathrm{TC}=$ total cost. 


\section{RESULTS}

The socio-economic attributes of the respondents in the study area is presented on Table 1 . The results showed majority (38\%) of respondents were between 26 and 35 years old. Most of the nurseries operators were male (53\%) while $48 \%$ of the respondents engaged in plant nurseries operation were female. The educational level of the respondents showed most of the seedling nurseries within the study area had education background with $49 \%$ of the people had attended secondary school, tertiary educational level was $23 \%$ and Primary school level was $18 \%$ while $9 \%$ had non-formal education in the study area. Most (68\%) of the respondents interviewed were single and $32 \%$ were married while there was no divorced, separation or widow/widower among the nursery operations. Muslims were the majority (53\%) that engaged in plant nurseries operation, followed by Christians (40\%) and the traditionalist were $5 \%$ while $2 \%$ of the respondents didn't practiced religion in the study area.

Table1. Socio-economic Attributes of Respondents in Bauchi Metropolis, Nigeria

\begin{tabular}{|l|l|l|l|}
\hline Variables & Category & Frequency & Percentage \\
\hline Age & $18-25$ years & 34 & 28.3 \\
\hline & $26-35$ years & 46 & 38.3 \\
\hline & $36-45$ years & 23 & 19.2 \\
\hline & $46-55$ years & 17 & 14.2 \\
\hline & Total & $\mathbf{1 2 0}$ & $\mathbf{1 0 0}$ \\
\hline Gender & Male & 82 & 52.5 \\
\hline & Female & 38 & 47.5 \\
\hline & Total & $\mathbf{1 2 0}$ & $\mathbf{1 0 0 . 0}$ \\
\hline Educational level & Non formal education & 11 & 9.2 \\
\hline & Primary & 22 & 18.3 \\
\hline & Secondary & 59 & 49.2 \\
\hline & Tertiary & 28 & 23.3 \\
\hline & Total & $\mathbf{1 2 0}$ & $\mathbf{1 0 0 . 0}$ \\
\hline Marital status & Single & 82 & 68.3 \\
\hline & Married & 38 & 31.7 \\
\hline & Total & $\mathbf{1 2 0}$ & $\mathbf{1 0 0 . 0}$ \\
\hline Religion & Islam & 64 & 53.3 \\
\hline & Christianity & 48 & 40.0 \\
\hline & Traditional & 6 & 5.0 \\
\hline & Non & 2 & 1.7 \\
\hline & Total & & $\mathbf{1 0 0}$ \\
\hline
\end{tabular}

Source: Field survey, 2018

Based on the study, five seedling nurseries were selected within the study area. The seedling nurseries engaged in different activities which include: planting/tendering of seedlings, grafting, budding and mostly selling of seedling plants for various uses. Apart from selling of seedling plants, there were other services carried out by most of the nursery operators, these include: landscaping, private garden maintenance and seedling supplies. The rate of sufficiency of seedling produced was reported to be $10 \%$ insufficient, $40 \%$ sufficient and $60 \%$ highly sufficient.

Table 2 show categories of Job and employment status in the survey seedling nurseries within the study area. The result showed majority (72\%) of the respondents were working under the private nursery owners while $28 \%$ were the private nurseries owners (Managers). Most of the operators that were interview in the nurseries were on temporary employment $(71 \%)$ while $29 \%$ of the respondents were permanent workers working for themselves or managing the enterprise for the owner(s). This indicated that the workers engage into nurseries operation for time being due to poverty and lack of employment opportunity within Bauchi metropolis. Most (46\%) of the respondents had no other alternative job than seedling nurseries operation, they depend solely on nurseries enterprise for their income, while $53 \%$ of the respondents engaged in nursery enterprise had alternative jobs; either working as a civil servants or trading. 
Economic Analysis of Seedlings Plant Productions in Nurseries within Bauchi Metropolis in Nigeria

Table2. Job Categories and Employment Status among Nurseries Operators in Bauchi Metropolis

\begin{tabular}{|l|l|l|}
\hline Job categories & Frequency & Percentage \\
\hline Manager & 34 & 28.3 \\
\hline Employee & 86 & 71.7 \\
\hline Total & $\mathbf{1 2 0}$ & $\mathbf{1 0 0 . 0}$ \\
\hline Employment status & & \\
\hline Permanent & 35 & 29.2 \\
\hline Temporary & 85 & 70.8 \\
\hline Total & $\mathbf{1 2 0}$ & $\mathbf{1 0 0 . 0}$ \\
\hline Alternative jobs & & \\
\hline Trading & 31 & 25.8 \\
\hline Civil service & 34 & 28.3 \\
\hline None & 55 & 45.8 \\
\hline Total & $\mathbf{1 2 0}$ & $\mathbf{1 0 0 . 0}$ \\
\hline
\end{tabular}

Source: Field survey, 2018

\subsection{Initial Capital before Starting Nursery Enterprise and Price Unit per Seedling}

The initial capital to start a nursery enterprise and the average price unit per seedling is presented on Table 3. The initial capital of the nursery owners before they commenced the nursery enterprise in the study area revealed the highest initial capital was $\$ 50,000.00$ (43\%) and the least (9\%) had $¥ 150,000.00$. The average price unit per seedling sold in the nurseries within the study area showed that $\$ 150.00$ was the least price unit per seedling while above \#300.00 was the highest price unit, this study revealed that nurseries operation within Bauchi metropolis is really a source of income to those that engage in the operation. For land requirement, the lands used for the establishment of most of the seedling nurseries were rented at the cost of $\$ 5,000$ monthly, given a total of N60, 000 annually. Most of the nurseries owners used less than a plot (100 x 100 feet) for nurseries set up. It is also assumed that the labor used was self labour and the water sourced was mostly free (i.e. can be from stream, tape or well).

Table3. Initial Capital before Starting Nursery Business and Price Unit per Seedling in the Study Area

\begin{tabular}{|l|l|l|l|}
\hline Variable & Category (N) & Frequency & Percentage \\
\hline Initial capital before starting business & $<50,000.00$ & 51 & 42.5 \\
\hline & $50,000.00$ & 36 & 30.0 \\
\hline & $100,000.00$ & 22 & 18.3 \\
\hline & $150,000.00$ & 11 & 9.2 \\
\hline & Total & $\mathbf{1 2 0}$ & $\mathbf{1 0 0 . 0}$ \\
\hline Least unit price per seedling & 100.00 & 22 & 18.3 \\
\hline & 150.00 & 54 & 45.0 \\
\hline & 200.0 & 28 & 23.3 \\
\hline & $>200.00$ & 16 & 13.3 \\
\hline & Total & $\mathbf{1 2 0}$ & $\mathbf{1 0 0 . 0}$ \\
\hline
\end{tabular}

Source: field survey, 2018

Table 4 show available types of seedlings that were used for various purposes in the nurseries within the study area. Seedlings for ornamental and flower were the mostly (48\%) available type of seedlings planted in most of the nurseries, followed by fruits type of seedlings which had $21 \%$ while the least (2\%) available type of seedling in the study area was the plantation plant seedlings. Seedlings with multipurpose uses were the most $(37 \%)$ planted seedlings in, followed by beautification which had the $25 \%$, protection uses $20 \%$. This indicated that most nurseries engage in beautification than any other purposes in the study area.

Table4. Classification of Seedling Species by Nurseries in the Study Area

\begin{tabular}{|l|l|l|}
\hline Type of seedling & Frequency & Percentage \\
\hline Ornamental/Flowers & 58 & 48.3 \\
\hline Fruits & 25 & 20.8 \\
\hline Hedge & 16 & 13.3 \\
\hline Grasses & 11 & 9.2 \\
\hline Shade & 8 & 6.7 \\
\hline Plantation plants & 2 & 1.7 \\
\hline
\end{tabular}


Economic Analysis of Seedlings Plant Productions in Nurseries within Bauchi Metropolis in Nigeria

\begin{tabular}{|c|c|c|}
\hline Total & 120 & 100.0 \\
\hline \multicolumn{3}{|l|}{ Uses of seedling } \\
\hline Protection & 24 & 20.0 \\
\hline Beautification & 30 & 25.0 \\
\hline plantation establishment & 22 & 18.3 \\
\hline multipurpose & 44 & 36.7 \\
\hline Total & 120 & 100.0 \\
\hline
\end{tabular}

Source: field survey, 2018

\subsection{The Seedling Species Produced in the Nurseries within Bauchi Metropolis}

The seedlings identified at the nurseries in the study area comprised of 24 species. The seedling species belong to 17 different families. For ease of recognition of these seedling species, common names of each species were included and presented in Table 5. These species were indicator of marketable species in the study area. The most frequent and available seedling species encountered in the nurseries within the study area were Archontophoenix cunninghamiana m (7\%), Syagrus romanzoffiana (7), yellow bus Syagrus romanzoffiana h (7\%), followed by ficus benjamina plant which had $6 \%$, Polyalthia longifolia plant (5\%), Washingtonia robusta (5\%), grafted mango (Mangifera indica) seedlings 4\% while Psidium guajava, Casuarina equisetifolia, Elaeis guineensis and Carica papaya were the least (1\%) planted seedling species.

Table5. Seedling Species Produced in all the Nurseries within the Study Area

\begin{tabular}{|r|l|l|l|l|}
\hline S/N & Common name & Botanical Name & Family & Percent \\
\hline 1 & Mango & Mangifera indica & Anacardiaceae & 4 \\
\hline 2 & Masquerade tree & Polyalthia longifolia & Annonaceae & 5 \\
\hline 3 & Neem & Azadirachta indica & Meliaceae & 3 \\
\hline 4 & Coconut palm & Cocus nucifera & Arecaceae & 3 \\
\hline 5 & Flamboyant & Delonix regia & Leguminosae & 4 \\
\hline 6 & Eucalyptus & Eucalyptus camaldulensis & Lecythidaceae & 4 \\
\hline 7 & Ficus & Ficus benjamina & Moraceae & 6 \\
\hline 8 & Acalypha & Acalypha godseffiana & Euphorbiaceae & 2 \\
\hline 9 & Gmelina & Gmelina arborea & Lamiaceae & 2 \\
\hline 10 & Golden palm & Washingtonia robusta & Arecaceae & 5 \\
\hline 11 & Guava & Psidium guajava & Myrtaceae & 1 \\
\hline 12 & Cashew & Anacardium occidentale & Anacardiaceae & 3 \\
\hline 13 & Juja pine & Casuarina equisetifolia & Casuarinaceae & 1 \\
\hline 14 & King palm & Archontophoenix cunninghamiana & Arecaceae & 7 \\
\hline 15 & Single ixora & Ixora coccinea & Rubiaceae & 4 \\
\hline 16 & Step tree & Terminalia mentalis & Combretaceae & 4 \\
\hline 17 & Teak & Tectona grandis & Lamiaceae & 3 \\
\hline 18 & Umbrella tree & Terminalia catappa & Combretaceae & 2 \\
\hline 19 & Yellow bush & Duranta repens & Verbenaceae & 7 \\
\hline 20 & Oil palm & Elaeis guineensis & Arecaceae & 1 \\
\hline 21 & Orange & Citrus spp & Rutaceae & 4 \\
\hline 22 & Paw paw & Carica papaya & Caricaceae & 1 \\
\hline 23 & Pear & Pyrus spp & Rosaceae & 2 \\
\hline 24 & Queen palm & Syagrus romanzoffiana & 7 \\
\hline
\end{tabular}

Source: field survey, 2018

\subsection{Economic Evaluation of Nursery Seedlings}

The result of the economic analysis from this study is given in Table 6. The table show ornamental seedlings plant had the highest economic value of $64 \%$ which mean the seedlings are widely used within Bauchi metropolis, followed by tree crops with $23 \%$ economic value and forest tree species had $13 \%$ economic value as the lowest. Ornamental plants ranked the highest as a result of its patronage and accrued profit.

The rate of returns (RORT) which is the ratio of money gained from an investment relative to the amount of money invested was high with the highest returns on Golden Palm (N2,350), Ficus (N1,193.33), Yellow bush (N1,050) and Gmelina (N1,033.33).

The highest quantities of seedling species produced per year were Ixora (4000) and the least/lowest seedling species produced was Queen Palm which was 2000 in quantity per year. It showed that Step- 
trees (300) and Masquerade trees (3500) were not among the seedling with the highest returns yet they were produced in higher quantities due to high demand for these species. Forest plantation seedlings are produced in small quantities due to low demand; however they generate high returns whenever sold.

Table6. Mean Values of the Economics Analysis for Seedling Produced in the Study Area

\begin{tabular}{|l|l|l|l|l|l|l|}
\hline Seedling species & $\begin{array}{l}\text { Quantity sold per } \\
\text { annum }\end{array}$ & $\begin{array}{l}\text { Production } \\
\text { Cost } \\
\text { (N) }\end{array}$ & $\begin{array}{l}\text { Selling } \\
\text { Price/Seedling } \\
\text { (N) }\end{array}$ & $\begin{array}{l}\text { Total } \\
\text { Revenue } \\
\text { (N) }\end{array}$ & $\begin{array}{l}\text { Gross } \\
\text { Margin } \\
\text { (N) }\end{array}$ & RORT \\
\hline Tree crops (23\%) & & & & & & \\
\hline Cashew & 70 & 3,500 & 300 & 21,000 & 17,500 & 500 \\
\hline Coconut & 100 & 5,000 & 550 & 55,000 & 50,000 & 1000 \\
\hline Guava & 120 & 6,000 & 300 & 36,000 & 30,000 & 500 \\
\hline Mango & 400 & 20,000 & 500 & 200,000 & 180,000 & 900 \\
\hline Oil palm & 900 & 45,000 & 400 & 360,000 & 315,000 & 700 \\
\hline Orange & 200 & 10,000 & 466.67 & $93,333.33$ & $83,333.33$ & 833.33 \\
\hline Pawpaw tree & 70 & 3,500 & 250 & 17,500 & 14,000 & 400 \\
\hline Pear & 50 & 2,500 & 300 & 15,000 & 12,500 & 500 \\
\hline Forest trees (13.\%) & & & & & & \\
\hline Eucalyptus & 50 & 2,500 & 475.00 & 23,750 & 21,250 & 850 \\
\hline Gmelina & 40 & 2,000 & 566.67 & $22,666.67$ & $20,666.67$ & 1033.33 \\
\hline Neem & 60 & 3,000 & 300 & 18,000 & 1,500 & 500 \\
\hline Teak & 20 & 1,000 & 466.67 & $9,333.33$ & $8,333.33$ & 833.33 \\
\hline Ornamental plants (64\%) & & & & & & \\
\hline Acalypha & 120 & 6,000 & 250 & 30,000 & 24,000 & 400 \\
\hline Crocus & 150 & 7,500 & 300 & 45,000 & 37,500 & 500 \\
\hline Ficus & 3,000 & 150,000 & 646.67 & $1,940,000$ & $1,790,000$ & $1,193.33$ \\
\hline Flamboyant & 500 & 25,000 & 500 & 250,000 & 225,000 & 900 \\
\hline Golden palm & 1500 & 25,000 & 408.33 & 612,500 & 587,500 & 2350 \\
\hline Ixora & 4000 & $200,000.00$ & 383.33 & $1,533,333.33$ & $1,333,333.3$ & 666.67 \\
\hline Juja pine & 500 & $73,333.33$ & 366.67 & $183,333.33$ & 110,000 & 150 \\
\hline King palm & 2500 & 125,000 & 500 & $1,250,000$ & $1,125,000$ & 900 \\
\hline Masquerade tree & 3500 & 175,000 & 325 & $1,137,500$ & 962,500 & 550 \\
\hline Queen palm & 2000 & 100,000 & 487.50 & 975,000 & 875,000 & 875 \\
\hline Royal palm & 2500 & 125,000 & 350 & 875,000 & 750,000 & 600 \\
\hline Step tree & 3000 & 150,000 & 300 & 900,000 & 750,000 & 500 \\
\hline Umbrella tree & 500 & 25,000 & 550 & 275,000 & 250,000 & 1,000 \\
\hline Yellow bush & 3200 & 160,000 & 575 & $1,840,000$ & $1,680,000$ & 1,050 \\
\hline
\end{tabular}

Source: field survey, 2018

\subsection{Factors Hindering Seedlings Production in the Study Area}

Table 7 shows the constraints to seedlings production in nurseries in the study area. Problems encountered in the business by the various nurseries operator include: inadequate finance $(40 \%)$, transportation (9\%), pest and diseases (10\%), inadequate water supply (30\%) and shortage of propagules (11\%). Although from the economic evaluation the nursery business seemed viable, all nurseries within the study area reported inadequate finance problems as one of the major constraints followed by transportation of seedlings to customers poses a major setback due to lack of vehicles especially when large quantities of seedlings were ordered. Well water serves as the main source of water used by the nursery operators. This was usually sufficient during the rainy season but poses huge problems during the dry season especially since there was no adequate water supply system in the state

Table7. Constraints Affecting Seedlings Production in the Study Area

\begin{tabular}{|l|l|l|}
\hline Constraints & No. of nurseries & Percentage \\
\hline Inadequate finance & 48 & 40.0 \\
\hline Lack of transportation & 11 & 9.2 \\
\hline Pest and diseases & 12 & 10.0 \\
\hline Inadequate water supply & 36 & 30.0 \\
\hline Shortage of seeds/inputs & 13 & 10.8 \\
\hline Total & 120 & 100.0 \\
\hline
\end{tabular}

Source: field survey, 2018 


\section{DISCUSSION}

This age bracket composed of youths and few adults. This implies that nursery business in the study area can be greatly improved upon, since it is concentrated mostly in the hands of young and agile individuals. This result agreed with Babalola (2008), who reported that Nursery enterprises has significant potentials of providing reliable job opportunities for young graduate and other people in the society. This finding revealed that the respondents that engaged into nurseries operation in the study area were mostly males. The high number of male respondents over the female implied that ornamental plants production business was not popular among the women folks in the study area. This may be due to the high labour requirements for nursery operations or it could be as a result of shyness or religion which limits the level of women engagement in some activities and associating with the public.

This indicated that commercial nurseries operation in the study area is gradually acquiring reasonable formal educational background that could enable the nursery operators to operate improved technology in the nursery business. The literacy level of the respondents could affect their choice of inputs and the utilization of existing inputs and also their willingness to adopt improved technologies. The more educated the nursery owner is, the greater the production output and quality of the seedlings produced, because since their educational background enables them to adopt new and modern innovations and increase their risk management ability.

The plant nurseries in the study area engaged in different services and sales of seedlings plants for various uses; the nurseries operators supplied sufficient seedlings and provided services to the people in the study area. The major reasons why majority of the respondents operate in seedling production were for employment and income generation. This result is in accord with Larinde and Ruth (2014), who stated that Small scale private plant nursery enterprise is a self-employment business that can contribute to substantial employment, income generation and socio-economic development of a state.

The result on job categories and employment status implied that nursery enterprises contribute greatly to the economic status of the people in the study area. This indicated that most of the plant nurseries were being owned by private/individual within Bauchi metropolis. According to Filani et al. (1994) on the business operating in Ibadan revealed that small-scale business enterprise dominates Ibadan metropolis; the contributions of these private nurseries cannot be overlook as a results of its socioeconomic development to the study area.

This indicated that nursery enterprise was feasible even with small capital. Also, water availability was adequate depending on the location of nurseries within the study area.

The nurseries enterprise produced different seedlings which comprises of ornamental, flowers and fruits trees as the most produced seedling plants and hedge seedlings had the lowest percentage.

According to Laarman (2007), the strongest arguments in the development of policies and plans of action in forest management and planning involve economic analyses. This is important to understand whether it is financially feasible for people to engage in such forestry enterprises and what can be done.

The cost structure is the summation of the market prices of all purchased inputs and other imputed cost. This cost structure is equally dynamic in that it changes with time. This result on seedling nurseries establishments are highly profitable business ventures in Nigeria due to the short time between production and sale of most of the plants involved (Aiyeloja and Larinde. 2006).

Inadequate finance and water for irrigation of seedlings were the major constraints to nursery enterprise in the area. This result is in accord with Fakayode et al., (2008), reported that the most prevalent limitation to ornamental plants nursing business is the operators' inability to access adequate funds necessary to capitalize their farms. . During the dry season, shortage of water leads to water stress of seedlings and this invariably results in low survival rate and hence losses. Thus, the nurserymen reduce their selling prices to dispose seedlings that are incurring a higher production cost of watering. In contrast, there is a boost in production of seedlings in the rainy season, as more people are engaged in planting, which leads to increase in demand for the seedlings and subsequently increase in general unit selling prices. 


\section{CONCLUSION}

Based on this study, plant nursery enterprise is a viable means of income in Nigeria, which one can engage in as a mean of self employment instead of depending on Government for white collar jobs. Most of the nursery operators and owners were young and agile individuals. Twenty four species; 16 ornamental species, 10 tree crops and 4 forest tree species were identified in the study area. These species were considered indicators of marketable seedling species in the study area. Employment and income generation were the major reason why most of the respondents engaged in seedlings production. Apart from income generation, nursery as a business is another means of conservation of plant species and it has a great role in the control of environmental problem. The economic analysis from this study showed the rate of returns (RORT) was high with the highest returns on Ficus species ( $\$ 1,193.33)$, Yellow bush $(\$ 1,050)$ and Gmelina ( $\$ 1,033.33)$. Thus, commercial nursery business in the study area can be greatly improved upon, since it is concentrated mostly in the hands of young individuals. This finding also revealed that more ornamental plants were produced than forest tree species due to market demand. Inadequate funds and water supply were the major constraint to seedlings production in the study area; therefore, there is need for Government and NGOs to assist nursery operators with loan to start up or expand the existing nursery business.

\section{REFERENCES}

Dau, J.H. and Elisha, A.(2013): Survey on Non-Timber Forest Products in Bauchi South Senatorial Districts, Bauchi State, Nigeria; Journal Of Research In Forestry, Wildlife And Environmental ,6 (1): 82-97.

Mailumo, S.S., Okonkwo, M.C., and Afrika, B.M. (2006): Socio-economic analysis of tree seedlings production in nurseries: evidence from municipal area council, Abuja, FCT. Nigeria in: Popoola L (ed) Forestry at Cross roads in Nigeria. Proceeding of the 31st annual conference of forestry Association of Nigeria (FAN), held in Makurdi, Benue state, Nigeria, 20-23 Nov. Forestry Association of Nigeria, pp492-499.

National Bureau of Statistics/Central Bank of Nigeria (2006) Economic Survey on Nigeria. National Bureau of Statistics, Abuja.

Babalola, F.D. (2008) Assessment of Small Scale Private Nursery Enterprise in Ibadan, Oyo State Nigeria. Smallscale Forestry 7: Pp263-273.

Aiyeloja, A.A. and Larinde, S.L. (2006) Investment of Employment Opportunity in Small Scale Forest Based Enterprises: Proc.31st Conf. of Forestry Association of

Nigeria. Nov 2006, pp 449-453.

Laarman, J.G. (2007): The World Agroforestry Centre's experience in cross-sectoral policy planning in Africa: In Cross-Sectoral Policy Developments in Forestry (Y.C. Dube' and F. Schmithu" sen, Eds.), 82-88. CABI, Oxfordshire, United Kingdom.

Omokhua, G., Idumah, F.O and Abu, H.E (2002): The Prospects of Fruits Trees Crops to the Nigeria Economy. A Paper Presented at the 20th Annual Conference of Horticultural society of Nigeria.

Oseni,T.O (2004): "Integrated Horticultural Crop Production and Extension Services. A Paper Presented at the 22nd Annual Conference of Horticultural society of Nigeria.

Fakayode, B. S.; Adewumi, M.O.; Rahji, M.A.Y and Jolaiya J.A. (2008): Viability and Resource Use in Ornamental Plants Nursery Business in Nigeria; European Journal of Social Sciences - Volume 6 (4).

Farris, P.W., Neil T. B., Phillip E. P., and David J. R. (2010): Marketing Metrics: The Definitive Guide to Measuring Marketing Performance. Upper Saddle River, New Jersey: Pearson Education, Inc.

Larinde, S.L. \& Ruth S. (2014): Assessment of Small Scale Private Plant Nursery Enterprise in Port Harcourt, Rivers State; Global Journal Bioscience and Biotechnology; Vol.3 (3); pp: 301-311.

Citation: Ephraim, K. Rabo \& Abubakar, E. Mazadu, "Economic Analysis of Seedlings Plant Productions in Nurseries within Bauchi Metropolis in Nigeria", International Journal of Forestry and Horticulture (IJFH), vol. 4, no. 3, pp. 8-15, 2018. http://dx.doi.org/10.20431/2454-9487.0403002

Copyright: (1) 2018 Authors. This is an open-access article distributed under the terms of the Creative Commons Attribution License, which permits unrestricted use, distribution, and reproduction in any medium, provided the original author and source are credited. 